\title{
ISOTOPIC SIGNATURES OF PALEOPROTEROZOIC GRANITOIDS OF THE GAVIÃO BLOCK AND IMPLICATIONS FOR THE EVOLUTION OF THE SÃO FRANCISCO CRATON, BAHIA, BRAZIL
}

\author{
LUIZ ROGÉRIO BASTOS LEAL ${ }^{1}$, WILSON TEIXEIRA ${ }^{2}$, JOSÉ CARLOS CUNHA ${ }^{3}$, \\ ANGELA BEATRIZ DE MENEZES LEAL ${ }^{1}$, MOACIR JOSÉ BUENANO MACAMBIRA ${ }^{4}$ \\ AND MARIA DE LOURDES DA SILVA ROSA ${ }^{1}$
}

\begin{abstract}
Intense granitic plutonism of peraluminous and metaluminous calc-alkaline affinity took place in the northern sector of the São Francisco Craton, during the Paleoproterozoic. Rb-Sr and ${ }^{207} \mathrm{~Pb} /{ }^{206} \mathrm{~Pb}$ (zircon) radiometric data for the granitoids yield crystallization ages at ca. $2.0 \mathrm{Ga}$. The calculated ${ }^{87} \mathrm{Sr} /{ }^{86} \mathrm{Sr}$ initial ratios (up to 0.727$), \mathrm{T}_{\mathrm{DM}}$ model ages (between 2.6 and $3.5 \mathrm{Ga}$ ) and the range in the $\mathrm{e}_{\mathrm{Nd}(\mathrm{t})}$ values (5.8 to -13.4) are all compatible with participation of variable proportions of Archean crust material in the magma genesis of such plutons. Tectonically, these granites originated due to the Transamazonian collisional orogeny, which developed within large terranes of the Craton along the edge of the Archean Gavião Block.
\end{abstract}

Keywords: isotope geochemistry, geochronology, granites, crustal evolution

INTRODUCTION In the northern São Francisco Craton (SFC), several granitoids associated with syn and late- tectonic phases of the Transamazonian collisional orogeny (e.g., Carnaíba, Campo Formoso, Flamengo, Riacho de Pedras, Lagoinha, Lagoa Grande, and Caetano) have been identified (Sabaté et al. 1990, Santos-Pinto 1996) (Figs. 1A and B). They comprise a string of plutons bearing predominant peraluminous and subordinate metaluminous affinities, which are closely associated with a major NS structure of the Paleoproterozoic Contendas Mirante-Jacobina belt, which makes up the collision front due to tectonic convergence between the Archean Gavião and Jequié blocks. The mineralogical, chemical, and isotopic characteristics of the granitoids (e.g., Serra da Franga, Mariana, Umburanas, Rio of Paulo, Iguatemi, Caculé, Espírito Santo), at the southern portion of the Gavião Block (GB), near Brumado, reveal that the Archean gneissmigmatite terrain played an important role in the genesis of the parental magmas of these granitoids (e.g. Santos-Pinto 1996, Bastos Leal 1998).

Here we present a synthesis of ${ }^{207} \mathrm{~Pb} /{ }^{206} \mathrm{~Pb}$ (single zircon, evaporation), $\mathrm{Rb}-\mathrm{Sr}, \mathrm{Sm}-\mathrm{Nd}$ and $\mathrm{K}-\mathrm{Ar}$ determinations carried out on four Transamazonian granitoids (Rio do Paulo-RP, Caculé-CA, Iguatemi-IG, Espírito Santo-ES) that intrude the GB - Fig. 1B. Based on isotopic and geochemical data, the sources of these plutonic rocks are constrained, leading to discussion of the tectonic implications for the evolution of SFC.

GEOLOGICAL FRAMEWORK The GB comprises three main geological units (Fig. 1B): (i) granite-gneiss-migmatite terranes, dominated by associations of TTG-type orthogneisses and Archean granites with zircon $\mathrm{U}-\mathrm{Pb}$ and ${ }^{207} \mathrm{~Pb} /{ }^{206} \mathrm{~Pb}$ ages varying from $3403 \pm 5$ Ma to $3146 \pm 24 \mathrm{Ma}$; (ii) Archean greenstone belts with $\mathrm{Sm}-\mathrm{Nd}\left(\mathrm{T}_{\mathrm{DM}}\right.$ ) and zircon ${ }^{207} \mathrm{~Pb} / 206 \mathrm{~Pb}$ ages varying from 3,0 to $2,5 \mathrm{Ga}$; (iii) Paleoproterozoic granitoids (Bastos Leal 1998).

The Paleoproterozoic granites investigated (e.g., RP, CA, IG, ES) as well as many other granites are intrusive into both the greenstone belts and gneiss-migmatite terranes of the GB. These granitoids are gray to pink, coarse- to fine-grained, porphyritic, often slightly deformed. Their compositions vary from granodiorite to granite. In areas affected by Neoproterozoic regional shear zones, these plutons become pervasively lineated and/or foliated according to the orientation of the regional structures. In addition, the RP and CA granitoids host enclaves of mafic rocks, para- and orthogneisses, whereas the IG and ES bodies include enclaves of gneiss-migmatite rocks. A distinct compositional characteristic among the granitoids is the presence of amphibole and biotite in the essential mineralogy of the RP and CA massifs, whereas the IG and ES massifs are marked by the occurrence of muscovite.

GEOCHEMICAL FEATURES The geochemical characteristics of the studied granitoids vary from I-type granodiorites to S-type granites and define two different compositional groups in the AFM

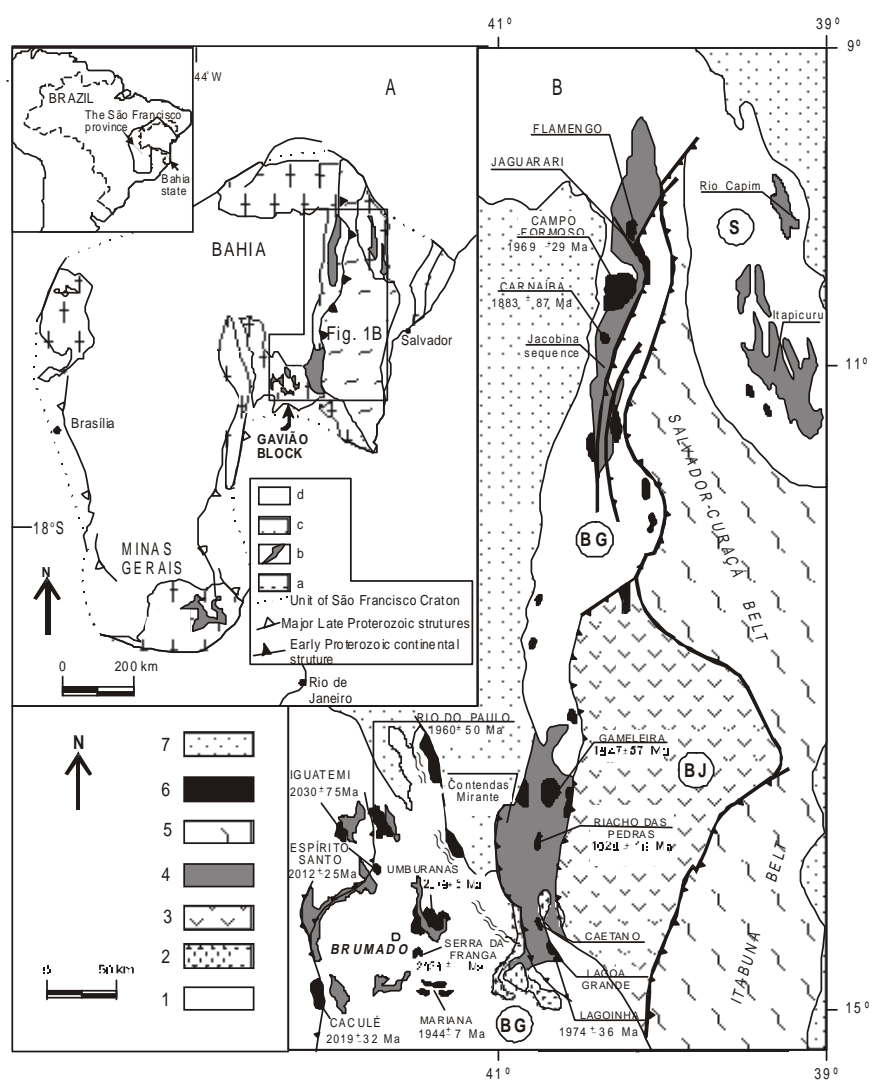

Figure 1 - Geological map of the studied area in the São Francisco Craton. A: $a$-Archean and Paleoproterozoic granitic-gneissic-migmatitic terranes; $b$ - Archean and Paleoproterozoic greenstone belts; c - Archean and Paleoproterozoic high grade rocks; $d$ - Post-Paleoproterozoic sedimentary covers (After Bastos Leal 1998, with modifications).

B: 1 - Archean gneissic-migmatitic terranes of the TTG suite; 2 - Archean granitoids; 3 - Jequié Block (Archean high grade gneiss); 4 -Archean/ Paleoproterozoic supracrustal sequence; 5 - Paleoproterozoic mobile belt; 6 - Transamazonian granitoids; 7- Meso/Neoproterozoic and Cenozoic covers (After Sabaté et al. 1990, with modifications).

diagram (Fig. 2A). RP and CA rocks show metaluminous character with a light peraluminous tendency in the case of RP. IG and ES rocks are dominantly peraluminous (Fig. 2B). It is also noticeable that the granitoids of all four massifs show a range of composicional variation similar to other Transamazonian granitoids of the GB and those closely associated with the CMJ (Figs. 2A and 2B).

1 - Departamento de Geoquímica, Instituto de Geociências da Universidade Federal da Bahia, Rua Barão de Geremoabo, S/N - Campus de Ondina, CEP: 40210190, Salvador, Bahia, Brasil. E-mail: 1rbleal@zaz.com.br

2 - Instituto de Geociências, Universidade de São Paulo, CEP 05508-900, São Paulo, SP, Brasil. E-mail: wteixeir@usp.br

3 - Companhia Baiana de Pesquisas Minerais-CBPM, 4ª avenida, 460 - Centro Administrativo da Bahia, CEP. 41750-300, Salvador, Bahia, Brasil. E-mail: zecunha@cbpm.br

4 - Centro de Geociências - Universidade Federal do Pará, C.P. 1611, CEP. 66059 - Belém - Pará, Brasil. E-mail: moamac@ ufpa.br 

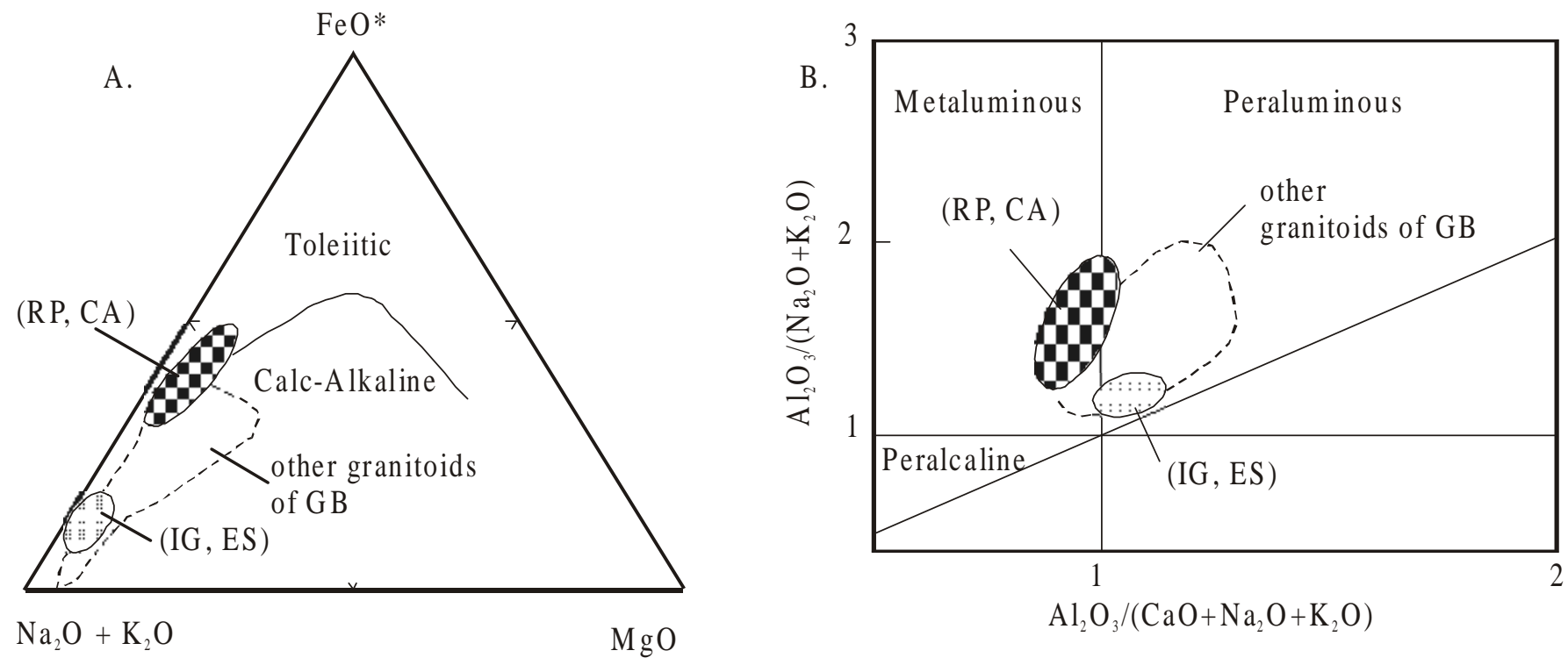

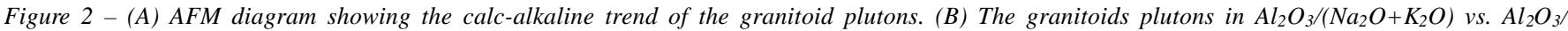
$\left(\mathrm{CaO}+\mathrm{Na}_{2} \mathrm{O}+\mathrm{K}_{2} \mathrm{O}\right)$ diagram.

The two groups of granitoid differ in their relationships between the LIL and HFS elements. The ratios from members of the RP and CA bodies include, respectively: $\mathrm{Rb} / \mathrm{Sr}(0,8$ and 0,5$), \mathrm{Rb} / \mathrm{Zr}(0,28$ and $0,16), \mathrm{Rb} / \mathrm{Hf}(13,2$ and 8,3$), \mathrm{K} / \mathrm{Rb}(228,7$ and 277,5$) \mathrm{Ta} / \mathrm{Hf}(0,11$ and $0,12)$ and $\mathrm{Ta} / \mathrm{Zr}(0,003$ and 0,002$)$ respectively. In contrast, the SE and IG rocks show, respectively: $\mathrm{Rb} / \mathrm{Sr}(4,7$ and 3,2$), \mathrm{Rb} / \mathrm{Zr}(2,4$ and 1,9$)$, $\mathrm{Rb} / \mathrm{Hf}(94,0$ and 60,2$), \mathrm{K} / \mathrm{Rb}(135,0$ and 165,0$), \mathrm{Ta} / \mathrm{Hf}(0,84$ and 0,64$)$ and $\mathrm{Ta} / \mathrm{Zr}(0,03$ and 0,02$)$. Such contrasts are thought to result from fundamental differences in the nature of the sources of these granitoids. In this context, geochemical data from RP and CA are compatible with those observed in calk-alkaline, I-type granitoids, while the geochemistry of IG and ES granitoids is similar to peraluminous granitoids formed in collisional orogens.

ANALYTICAL METHODS $\mathrm{Rb}-\mathrm{Sr}, \mathrm{Sm}-\mathrm{Nd}$ and $\mathrm{K}-\mathrm{Ar}$ isotopic analyses (Tables 1,2 and 4) were carried out at the Geochronologic Research Center of the University of São Paulo (CPGeo-USP), whereas zircon ${ }^{207} \mathrm{~Pb}-{ }^{206} \mathrm{~Pb}$ analyses (Table 3 ) were carried out at the Isotopic Geology Laboratory of the Federal University of Pará, Brazil (LGI-UFPA).

$\mathrm{Rb}$ and $\mathrm{Sr}$, and $\mathrm{Sm}$ and Nd contents in whole rocks (wr) were determined by X-ray fluorescence and isotopic dilution, respectively. The spectrometric readings of the ratios were done with a CPGeo's VG-354 mass spectrometer. The ${ }^{143} \mathrm{Nd} /{ }^{144} \mathrm{Nd}$ values were normalized using ${ }^{146} \mathrm{Nd} /{ }^{144} \mathrm{Nd}=0.7219$. Sm-Nd model ages $\left(\mathrm{T}_{\mathrm{PM}}\right)$ were calculated using the depleted mantle model proposed by DePaolo (1988). ${ }^{207} \mathrm{~Pb} /$ ${ }^{206} \mathrm{~Pb}$ analyses using the single zircon evaporation technique followed the procedures proposed by Gaudette et al. (1998).
Table 1 - Rb/Sr analytical data of the granitoids. The initial ${ }^{87} \mathrm{Sr}{ }^{86} \mathrm{Sr}$ were calculated for the crystallization time of the rocks.

\begin{tabular}{|c|c|c|c|c|c|c|}
\hline Granitoid & sample & $\begin{array}{c}\mathbf{R b} \\
(\mathbf{p p m})\end{array}$ & $\begin{array}{c}\begin{array}{c}\text { Sr } \\
(\mathbf{p p m})\end{array} \\
\end{array}$ & $\begin{array}{c}{ }^{87} \mathbf{R b} /{ }^{86} \mathrm{Sr} \pm \\
\text { error }\end{array}$ & ${ }^{87} \mathrm{Sr} /{ }^{86} \mathrm{Sr} \pm$ error & $\begin{array}{c}{ }^{87} \mathrm{Sr}^{866} \mathrm{Sr}(\mathbf{i}) \\
(\text { (i) }\end{array}$ \\
\hline \multirow{6}{*}{$\mathbf{R P}$} & \begin{tabular}{|l|} 
BR-JC-68A \\
\end{tabular} & 108,0 & 203,9 & $1,540 \pm 0,043$ & $0,75548 \pm 0,00013$ & 0.7120 \\
\hline & \begin{tabular}{|l} 
BR-JC-68E \\
\end{tabular} & 105,1 & 169,3 & $1,807 \pm 0,051$ & $0,76525 \pm 0,00007$ & 0.7142 \\
\hline & \begin{tabular}{|l} 
BR-JC-68G \\
\end{tabular} & 445,1 & 181,8 & $7,242 \pm 0,200$ & $0,93150 \pm 0,00008$ & 0.7030 \\
\hline & \begin{tabular}{|l} 
BR-JC-68I \\
\end{tabular} & 156,2 & 181,4 & $2,508 \pm 0,070$ & $0,77378 \pm 0,00009$ & 0.7271 \\
\hline & \begin{tabular}{|l|} 
BR-JC-68M \\
\end{tabular} & 225,0 & 126.6 & $5,216 \pm 0,145$ & $0.84982 \pm 0,00008$ & 0.7026 \\
\hline & BR-JC-68N & 148,3 & 126,8 & $3,417 \pm 0,096$ & $0,80339 \pm 0,00010$ & 0.7069 \\
\hline \multirow{6}{*}{ CA } & \begin{tabular}{|l|} 
BR-JC-234 \\
\end{tabular} & 145,9 & 342,2 & $1,239 \pm 0,035$ & $0,74539 \pm 0,00009$ & 0.7097 \\
\hline & \begin{tabular}{|l|} 
BR-JC-229 \\
\end{tabular} & 203,0 & 298,1 & $1,982 \pm 0,056$ & $0,76252 \pm 0,00009$ & 0.7054 \\
\hline & \begin{tabular}{|l|} 
BR-JC-237A \\
\end{tabular} & 174,0 & 300,2 & $1,686 \pm 0,047$ & $0,75860 \pm 0,00011$ & 0.7100 \\
\hline & \begin{tabular}{|l|} 
BR-JC-237AA \\
\end{tabular} & 203,5 & 321,9 & $1,839 \pm 0,052$ & $0,76144 \pm 0,00009$ & 0.7085 \\
\hline & \begin{tabular}{|l|} 
BR-JC-237BB \\
\end{tabular} & 176,5 & 276,8 & $1,855 \pm 0,052$ & $0,75750 \pm 0,00011$ & 0.7041 \\
\hline & \begin{tabular}{|l|} 
BR-07A \\
\end{tabular} & 166,9 & 301,8 & $1,608 \pm 0,045$ & $0,75580 \pm 0,00007$ & 0.7095 \\
\hline \multirow{4}{*}{ ES } & BR-01A & 349,7 & 56,8 & $18,722 \pm 0,504$ & $1,22205 \pm 0,00009$ & 0.6827 \\
\hline & \begin{tabular}{|l|} 
BR-01G \\
\end{tabular} & 349,8 & 62,1 & $17,083 \pm 0,461$ & $1,19327 \pm 0,00080$ & 0.7011 \\
\hline & \begin{tabular}{|l|} 
BR-01L \\
\end{tabular} & 337,5 & 69,4 & $14,653 \pm 0,398$ & $1,12419 \pm 0,00060$ & 0.7021 \\
\hline & BR-01P & 383,8 & 56,8 & $20,637 \pm 0,553$ & $1,26848 \pm 0,00043$ & 0.6734 \\
\hline \multirow{5}{*}{ IG } & 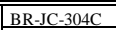 & 2799,3 & 80,5 & $\begin{array}{c}10,340 \pm 0,284 \\
\end{array}$ & $1,00888 \pm 0,00007$ & 0.7110 \\
\hline & BR-JC-304D & 300,6 & $\begin{array}{l}84,0 \\
605\end{array}$ & $10,668 \pm 0,293$ & $1,01208 \pm 0,00009$ & 0.7048 \\
\hline & \begin{tabular}{|l} 
BR-JC-304F \\
BR-JC-304G
\end{tabular} & $\frac{269,3}{198,8}$ & $\begin{array}{l}60,5 \\
66,3\end{array}$ & $\frac{13,347 \pm 0,364}{8,910 \pm 0,245}$ & $\frac{1,07357 \pm 0,00009}{0,97824+0,00011}$ & $\frac{0.6891}{0.7216}$ \\
\hline & \begin{tabular}{|l|} 
BR-JC-304J \\
\end{tabular} & 264,7 & 97,5 & $7,881 \pm 0,222$ & $0,93770 \pm 0,00013$ & 0.7107 \\
\hline & \begin{tabular}{|l|} 
BR-JC-309 \\
\end{tabular} & 242,9 & 135,9 & $5,248 \pm 0,146$ & $0,85406 \pm 0,00008$ & 0.7028 \\
\hline
\end{tabular}

Table 2 - Sm/Nd analytical data for granitoids. The isotopic ratios are at 2-sigma level, and the $e_{N d(t)}$ were calculated for the time of emplacement of the rocks using De Paolo (1988) model.

\begin{tabular}{|c|c|c|c|c|c|c|c|c|c|}
\hline Granitoid & sample & Sm (ppm) & Nd (ppm) & $\begin{array}{c}{ }^{147} \mathrm{Sm} /{ }^{144} \mathrm{Nd} \\
\pm \text { error }\end{array}$ & $\begin{array}{c}{ }^{143} \mathrm{Nd} /{ }^{144} \mathrm{Nd} \\
\pm \text { error }\end{array}$ & fSm/Nd & $\begin{array}{r}\mathbf{T}_{\mathbf{D}} \\
\mathrm{M}\end{array}$ & $\begin{array}{c}\mathrm{eNd}(\mathrm{t}) \\
\mathrm{t}=\mathbf{2 . 0} \\
\mathrm{Ga}\end{array}$ & $\varepsilon \mathrm{Ed}(\mathrm{o})$ \\
\hline$\overline{\mathbf{R P}}$ & BR-JC-68A & $14,731 \pm 0,008$ & $80,945 \pm 0,032$ & $0,1107 \pm 0,0001$ & $0,511214 \pm 0,000028$ & $-0,44$ & $\begin{array}{r}2,7 \\
3\end{array}$ & $-6,1$ & $-27,8$ \\
\hline \multirow[t]{2}{*}{$\overline{\mathrm{CA}}$} & $\overline{\text { BR-07A }}$ & $\overline{4} 45,590 \pm 0,024$ & $323,333 \pm 0,123$ & $0,0858 \pm 0,0001$ & $0,510849 \pm 0,000039$ & $-0,56$ & $\begin{array}{r}2,6 \\
3\end{array}$ & $-6,8$ & $-34,9$ \\
\hline & BR-JC-234 & $2,990 \pm 0,001$ & $18,682 \pm 0,006$ & $0,0974 \pm 0,0001$ & $0,510944 \pm 0,000037$ & $-0,50$ & $\begin{array}{r}2,7 \\
7 \\
\end{array}$ & $-7,9$ & $-33,0$ \\
\hline \multirow[t]{2}{*}{ ES } & BR-01L & $5,769 \pm 0,004$ & $33,972 \pm 0,016$ & $0,1033 \pm 0,0001$ & $0,510860 \pm 0,000024$ & $\begin{array}{l}-0,47 \\
\end{array}$ & $\begin{array}{r}3,0 \\
5\end{array}$ & $-111,1$ & $-34,7$ \\
\hline & BR-01S & $7,947 \pm 0,003$ & $48,061 \pm 0,019$ & $0,1006 \pm 0,0001$ & $0,510778 \pm 0,000024$ & $-0,49$ & $\begin{array}{c}3,0 \\
9\end{array}$ & $-12,0$ & $-36,3$ \\
\hline \multirow[t]{2}{*}{ IG } & BR-JC-309 & $13,519 \pm 0,008$ & $76,148 \pm 0,029$ & $0,1080 \pm 0,0001$ & $0,511034 \pm 0,000023$ & $-0,45$ & $\begin{array}{r}2,9 \\
3 \\
\end{array}$ & $-8,9$ & $-31,3$ \\
\hline & BR-JC-304J & $10,939 \pm 0,004$ & $55,369 \pm 0,021$ & $0,1202 \pm 0,0001$ & $0,510963 \pm 0,000025$ & $-0,39$ & $\begin{array}{r}3,4 \\
6\end{array}$ & $-13,4$ & $-32,7$ \\
\hline
\end{tabular}


ISOTOPIC RESULTS AND DISCUSSION Rio do Paulo

$\mathrm{Rb}$-Sr analyses of six samples from RP yielded a crystallization age of $1959 \pm 50 \mathrm{Ma}$ and initial ratio ${ }^{87} \mathrm{Sr} /{ }^{86} \mathrm{Sr}_{\mathrm{i}}(\mathrm{IR})=0.7108 \pm 0.0017$ $(\mathrm{MSWD}=9.2)($ Fig. $3 \mathrm{~A}$; Table 1$)$. A Sm/Nd model age $\left(\mathrm{T}_{\mathrm{DM}}\right)$ of 2.73

Table 3 - Evaporation data for zircons from the granitoids.

\begin{tabular}{|c|c|c|c|c|c|}
\hline Granitoid & $\begin{array}{c}\text { sample/ } \\
\text { no }^{\mathbf{0}} \text { zircon }\end{array}$ & \begin{tabular}{|c|}
$n^{0}$ of \\
rations
\end{tabular} & $\begin{array}{c}{ }^{204} \mathrm{~Pb} /{ }^{206} \mathrm{~Pb} \\
\pm \text { error }\end{array}$ & $\begin{array}{c}{ }^{207} \mathbf{P b} /{ }^{206} \mathrm{~Pb} \\
\pm \text { error }\end{array}$ & $\begin{array}{c}\text { Age } \\
\text { (Ma) } \\
\pm \text { error }\end{array}$ \\
\hline \multirow{6}{*}{ CA } & BR-JC-237/6 & 42 & $\begin{array}{c}0,000833 \\
\pm \\
0,000119\end{array}$ & $\begin{array}{c}0,119651 \\
\pm 0,003688\end{array}$ & $\begin{array}{l}1956 \\
\pm 56\end{array}$ \\
\hline & BR-JC-237/9 & 42 & $\begin{array}{c}0,000553 \\
\pm 0,000173 \\
\end{array}$ & $\begin{array}{c}0,122033 \\
\pm 0,003693 \\
\end{array}$ & $\begin{array}{l}1988 \\
\pm 54 \\
\end{array}$ \\
\hline & BR-JC-237/10 & 36 & $\begin{array}{c}0,000175 \\
\pm \\
0,000113 \\
\end{array}$ & $\begin{array}{c}0,123969 \\
\pm 0,001915\end{array}$ & $\begin{array}{l}2015 \\
\pm 27\end{array}$ \\
\hline & BR-JC-237/15 & 30 & $\begin{array}{c}0,000101 \\
\pm \\
0,000102 \\
\end{array}$ & $\begin{array}{c}0,127521 \\
\pm 0,005508\end{array}$ & $\begin{array}{l}2070 \\
\pm 72\end{array}$ \\
\hline & BR-JC-237/19 & 66 & $\begin{array}{c}0,000270 \\
\pm \\
0,000066\end{array}$ & $\begin{array}{c}0,123630 \\
\pm 0,002173\end{array}$ & $\begin{array}{l}2012 \\
\pm 31\end{array}$ \\
\hline & BR-JC-237/20 & 18 & $\begin{array}{c}0,000634 \\
\pm \\
0,000643 \\
\end{array}$ & $\begin{array}{c}0,122569 \\
\pm 0,012870\end{array}$ & $\begin{array}{c}1999 \\
\pm 186\end{array}$ \\
\hline \multirow[t]{2}{*}{$\overline{\text { ES }}$} & BR-01/2 & 30 & $\begin{array}{c}0,000167 \\
\pm \\
0,000173 \\
\end{array}$ & $\begin{array}{c}0,122033 \\
\pm 0,003693\end{array}$ & $\begin{array}{l}1997 \\
\pm 32\end{array}$ \\
\hline & BR-01/6 & 78 & $\begin{array}{c}0,000291 \\
\pm \\
0,000055 \\
\end{array}$ & $\begin{array}{c}0,124444 \\
\pm 0,001849\end{array}$ & $\begin{array}{l}2023 \\
\pm 26\end{array}$ \\
\hline
\end{tabular}

A.

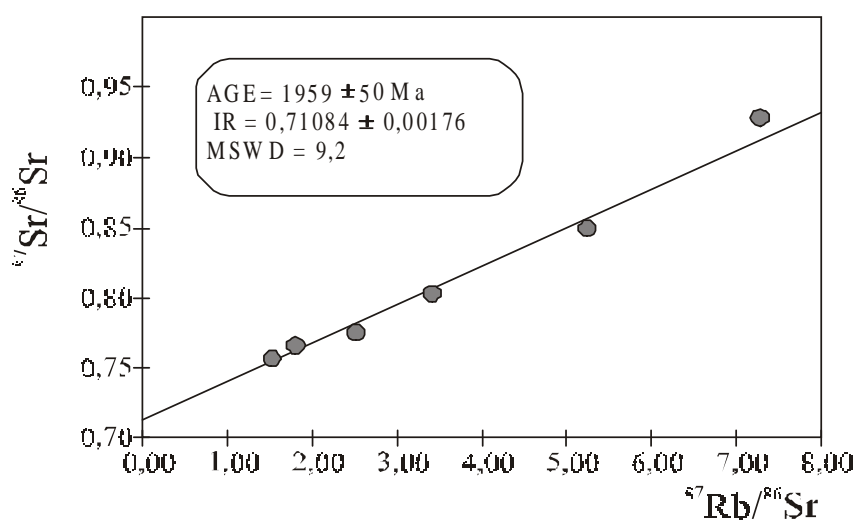

$\square$

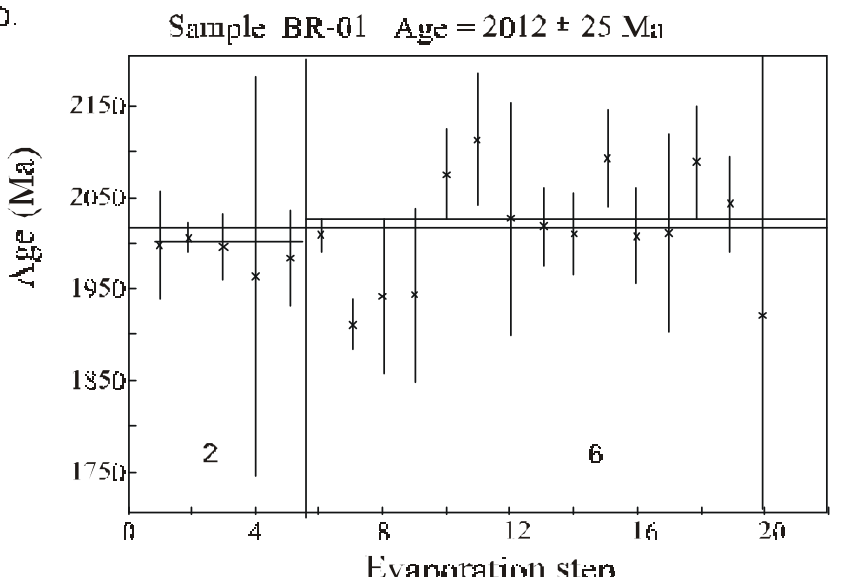

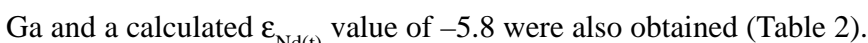
The high values of the IR coupled with the negative $\varepsilon_{N d}(t)$ suggest the involvement of crustal material in the genesis of this granitoid.

$\mathrm{K}-\mathrm{Ar}$ analysis in biotite from the RP body yielded $507 \pm 6 \mathrm{Ma}$ (Table 4), indicating a thermal overprint and complete argon loss during the Neoproterozoic.

Caculé Isotopic analyses in six zircon crystals of the CA granitoid produced a ${ }^{207} \mathrm{~Pb} / 206 \mathrm{~Pb}$ crystallization age of $2019 \pm 32 \mathrm{Ma}(2 \mathrm{~s}$ ) (Fig. 3B; Table 3). Rb-Sr analyses of six samples yielded an errochron of $1734 \pm 127 \mathrm{Ma}$ and high IR $=07146 \pm 00030$ (Table 1). There is a significant age difference between the ${ }^{207} \mathrm{~Pb} /{ }^{206} \mathrm{~Pb}$ and $\mathrm{Rb} / \mathrm{Sr}$ methods within the error, suggesting that the $\mathrm{Rb}-\mathrm{Sr}$ system was isotopically disturbed after emplacement of the CA. We interpret such a disturbance as possibly linked to the late Meso- to Neoproterozoic

Table $4-K /$ Ar analytical data of the granitoids

\begin{tabular}{|c|c|c|c|c|c|c|}
\hline Granitoid & sample & mineral & $\begin{array}{c}\% \mathbf{k} \\
\pm \\
\text { error }\end{array}$ & $\begin{array}{l}{ }^{40} \text { Arrad } \\
\left(X 10^{-6}\right) \\
\text { cCSTP/g }\end{array}$ & ${ }^{40}{ }^{\text {atm }} \mathrm{Ar} \%$ & $\begin{array}{c}\text { Age } \\
\text { 土error } \\
\text { (Ma) }\end{array}$ \\
\hline $\mathbf{R P}$ & BRJC-68G & Biotite & $\begin{array}{r}7,56 \\
\pm 0,5 \\
\end{array}$ & 172,0 & 6,4 & $\begin{array}{l}507 \\
\pm 6 \\
\end{array}$ \\
\hline \multirow[t]{2}{*}{$\mathbf{C A}$} & BRJC-237D & Amphib. & $\begin{array}{r}2,68 \\
\pm 0,5 \\
\end{array}$ & 151,0 & 1,1 & $\begin{array}{c}1064 \pm \\
12 \\
\end{array}$ \\
\hline & BRJC-237D & Biotote & $\begin{array}{r}7,06 \\
\pm 0,5 \\
\end{array}$ & 176,7 & 5,6 & $\begin{array}{r}551 \\
\pm 6 \\
\end{array}$ \\
\hline ES & BR-01A & Biotite & $\begin{array}{r}7,64 \\
\pm 2,3 \\
\end{array}$ & 167,2 & 2,9 & $\begin{array}{r}490 \\
\pm 12 \\
\end{array}$ \\
\hline IG & BRJC-304A & Biotite & $\begin{array}{r}7,34 \\
\pm 0,5\end{array}$ & 157,8 & 4,9 & $\begin{array}{r}483 \\
\pm 6 \\
\end{array}$ \\
\hline
\end{tabular}

B.
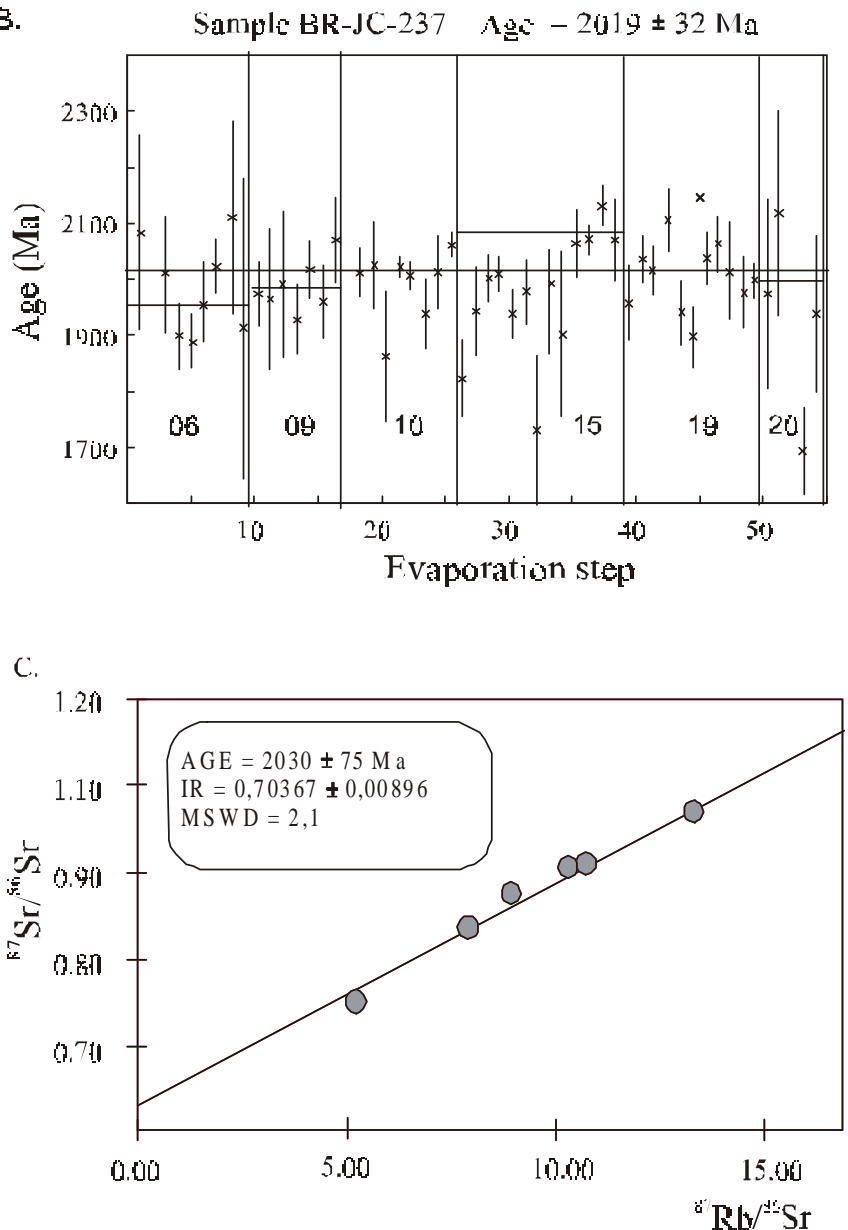

Figure 3 - (A) - Rb-Sr whole rock isochron of the Rio do Paulo granitoid; (B) - Diagram of Age vs. Number of blocks with six ${ }^{207} \mathrm{~Pb}{ }^{206} \mathrm{~Pb}$ ratios for zircons of the Cacule granitoid. " $x$ " - neglected blocks; the zircon grain number is indicated; $(C)$ - Rb-Sr whole rock isochron of the Iguatemi granitoid; $(D)$ - Diagram of Age vs. Number of blocks with six ${ }^{207} \mathrm{~Pb}{ }^{206} \mathrm{~Pb}$ ratios for zircons of the Espirito Santo granitoid. " $x$ " - neglected blocks; the zircon grain number is indicated. 

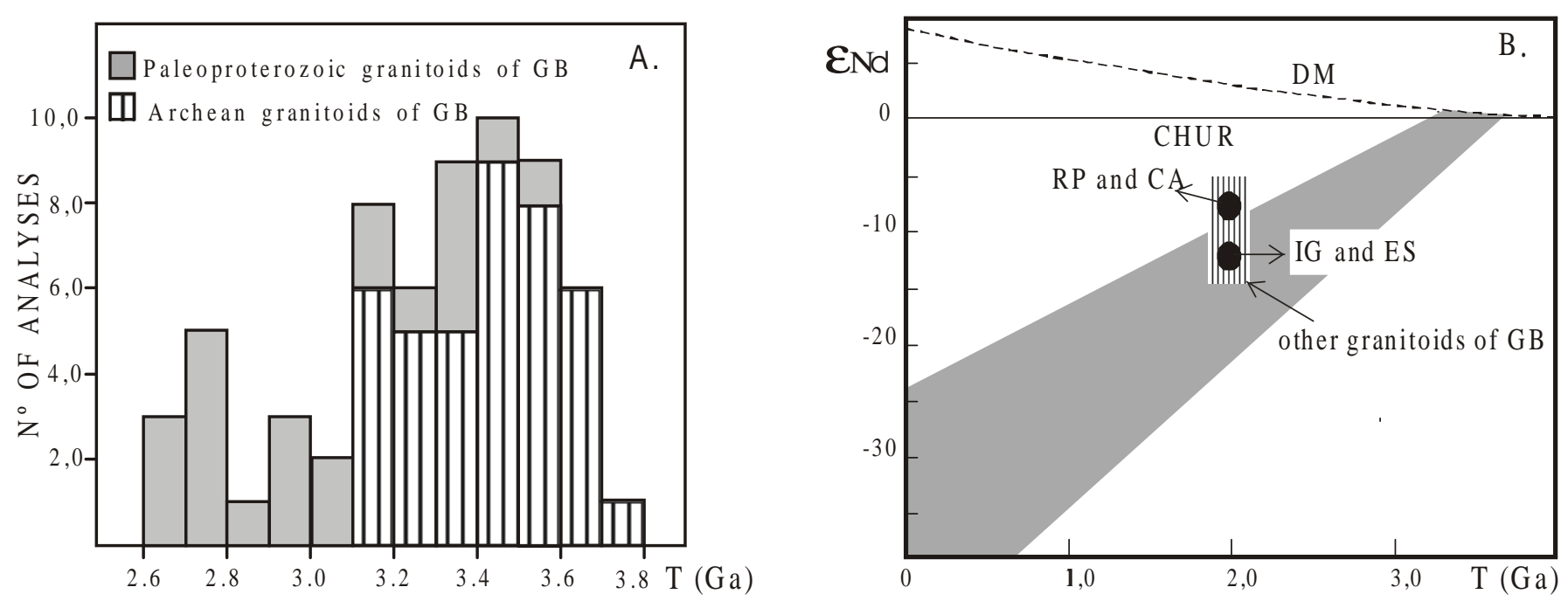

Figure $4-(A)$ - Nd isotopic evolution for the Archean TTG gneissic-migmatitic rocks $(G B)$ through time and variation of $\varepsilon_{N d}(t)$ values (for $t \approx 2.0$ Ga) of the granitoid plutons of Gavião block and Contendas Mirante-Jacobina belt. (B) - Sm-Nd model ages (Ga) for the Archean TTG gneissic-migmatitic and Transamazonic granitoid plutons of the BG and Contendas Mirante-Jacobina belt.

shear zones developed within this granitoid (see Fig. 1B). Further evidence of the tectonism is given by the K-Ar ages on amphibole $(1064 \pm 12 \mathrm{Ma})$ and biotite $(551 \pm 6 \mathrm{Ma})$, as well as by the $\mathrm{K}-\mathrm{Ar}$ date on the RP granitoid - see above and Table 4.

Two CA samples yielded T model ages of 2.63 and $2.74 \mathrm{Ga}$ with $\varepsilon_{\text {att }}$ values of -6.8 and -7.9 , respectively (Table 2). These values, together with the calculated IRs for the six samples analyzed $(0.7040$ 0.7100 ; see Table 1) suggest again the participation of different proportions of crustal components in the formation of this pluton.

Iguatemi Rb-Sr isotopic analyses of six samples of the IG massif yielded an isochron with a crystallization age of $2030 \pm 75 \mathrm{Ma}$ $(\mathrm{MSWD}=2.1)$ and $\mathrm{IR}=0.7036 \pm 0.0089$ (Fig. $3 \mathrm{C}$; Table 1). The $\mathrm{T}$ model ages are 2.93 and $3.46 \mathrm{Ga}$, with $\varepsilon_{\mathrm{Nd}(\mathrm{t})}$ values of -8.9 and -13.4 , respectively (Fig. 2). It is important to note the variations of IRs for each sample (from very low ones up to 0.7216 ; Table 1 ) and of model ages (see above) clearly showing heterogeneity in the crustal sources of the parental magmas, in agreement with previous interpretations (Sabaté et al. 1990, Pimentel \& Charnley 1991).

$\mathrm{K}-\mathrm{Ar}$ analysis in biotite revealed an age of $483 \pm 5 \mathrm{Ma}$ (Table 4), confirming the superposition of Neoproterozoic tectonothermal events within large areas of the GB.

Espírito Santo Analyses of four zircon crystals from the ES massif yielded a ${ }^{207} \mathrm{~Pb} /{ }^{206} \mathrm{~Pb}$ crystallization age of $2012 \pm 25 \mathrm{Ma}(2 \mathrm{~s})$ (Fig. 3D; Table 3). In contrast, Rb-Sr analyses of four samples of this massif revealed poorly linear array with $1684 \pm 179 \mathrm{Ma}$, with IR = $0.7721 \pm 0.0448$ (Table 1). Similarly to the case of the CA massif (see above), the age differences between the ${ }^{207} \mathrm{~Pb} /{ }^{206} \mathrm{~Pb}$ and $\mathrm{Rb}-\mathrm{Sr}$ methods in the ES granitoid probably reflects late partial reequilibration of the $\mathrm{Rb}-\mathrm{Sr}$ system.

$\mathrm{T}_{\mathrm{DM}}$ model ages of 3.05 and $3.09 \mathrm{Ga}$ and $\varepsilon_{\mathrm{Nd}(\mathrm{t})}$ values of $-11,1$ and $-12,0$ respectively (Table 2 ) suggest a crustal source for this granitoid, in conformity with the geochemical characteristics of the ES rocks (especially high $\mathrm{Rb} / \mathrm{Zr}, \mathrm{Rb} / \mathrm{Hf}$ and $\mathrm{Ta} / \mathrm{Hf}$ ratios) and mineralogical associations (biotite and muscovite). In addition, the $\mathrm{K}-\mathrm{Ar}$ age on biotite for this granitoid is $490 \pm 12 \mathrm{Ma}$ (Table 4), confirming again the cooling of the isotopic system resulted from the recognized Neoproterozoic tectonics (see Fig. 1B).

The four Paleoproterozoic granites clearly show the involvement of Archean gneissic-migmatitic materials of the GB in the magma genesis, as evidenced by Sm-Nd data compilation plotted in Figs 4 A and $\mathrm{B}$. The isotopic feature is similar to that seen in the contemporary metaluminous and peraluminous granitoids which crop out along the Contendas-Mirante Jacobina belt (see Sabaté et al. 1990).

Among the four plutons investigated, RP and CA exhibit the youngest $T_{\text {py }}$ ages $(2.6-2.7 \mathrm{Ga})$ and higher $\varepsilon_{\text {(t) }}(-5.8$ to -7.9$)$ values. Their Sm-Nd data plot between the curves of the depleted mantle and of the BG crust, therefore providing evidence the mixture of crustal and mantle components in the generation of both plutons. In contrast, IG and SE samples yield the oldest $\mathrm{T}_{\mathrm{DM}}$ ages (3.0-3.4 Ga) and lowest $\varepsilon_{\text {Nd(t) }}$ values (-11.1 to -13.4$)$, clearly supporting a major crustal source for these granitoids (see Fig 4B).

SUMMARY AND CONCLUSIONS Petrographic, geochemical, and isotopic features presented for RP, CA, ES and IG granitoids allow subdivide them into two different plutonic groups. Our data also suggest that the genesis of the parental magmas of these granitoids, at about $2.0 \mathrm{Ga}$ ago, was related to different sources and degrees of interaction between crustal and mantle materials. The plutonism was originated during the Transamazonian collisional tectonics within the northern São Francisco Craton.

RP and CA granitoids are characterized by amphibole- and biotitebearing assemblages. They show metaluminous affinity, lower LIL/ HFS ratios compared to ES and IG plutons, IRs between 0.703 and

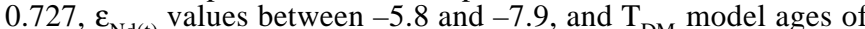
2.6-2.7 Ga. From the above parameters the RP and CA granitoids probably originated from partial melting of a subducting lithosphere (juvenile), with involvement of the Archean continental material from the BG.

The ES and IG granitoids, however, have characteristic biotite + muscovite mineralogy, peraluminous character, higher LIL/HFS ratios, significantly older $\mathrm{T}_{\mathrm{DM}}$ model ages (3.0-3.4 Ga), and lower negative $\varepsilon_{\mathrm{Nd}(t)}$ values $(-11,1$ to $-13,4)$. These bodies were probably derived from anatexis of the GB rocks including upper crust material.

Acknowledgements This paper was supported by the Fundação de Amparo à Pesquisa do Estado de São Paulo - FAPESP (grants 94/0999-5; 95/4652-2), and by Companhia Bahiana de Pesquisa Mineral - CBPM, Brazil. To two referees of RBG for the critical review of the manuscript.

\section{References}

Bastos Leal L.R. 1998. Geocronologia U/Pb (Shrimp), ${ }^{207} \mathrm{~Pb}{ }^{206} \mathrm{~Pb}, \mathrm{Rb} / \mathrm{Sr}$, Sm/Nd e K/Ar dos terrenos granito-greenstone do Bloco do Gavião: Implicações para a evolução
arqueana e paleoproterozóica do Cráton do São Francisco, Brasil. IG-USP, São arqueana e paleoproterozoica do Crât
Paulo, Tese de doutoramento, $176 \mathrm{p}$.

Bastos Leal L.R., Teixeira W., Cunha J.C., Macambira M.J.B. 1998. Archean tonalitictrondhjemitic and granitic plutonism in the Gavião block, São Francisco craton, trondhjemitic and granitic plutonism in the Gavião block, São Francisco craton, Bahia, Brazil: geochemical and geo

De Paolo D.J. 1988. Neodymium isotope geochemistry. An introduction. Springer Verlarg.

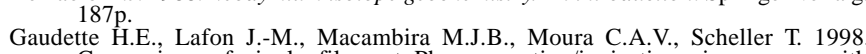
Comparison of single filament $\mathrm{Pb}$ evaporation/ionization zircon ages with conventional U-Pb results: examples from Precambrian of Brazil. Journal of South American Earth Sciences, 11:351-363.
Pimentel M.M. and Charnley N. 1991. Intracrustal REE fractional and implications for Sm$\mathrm{Nd}$ model age calculations in late satage granitic rocks: an example from central Brazil. Chemical Geology, 86: 123-138.

Sabaté P., Marinho M.M., Vidal P., Vachette M. 1990. The 2-Ga peraluminous magmatism of the Jacobina-Contendas Mirante belts (Bahia, Brazil): geologic and isotopic constraints on the sources. Chemical Geology, 83:325-338.

Santos-Pinto M. 1996. Le recyclage de la croúte continentale archéene: Exemple du bloc du Gavião - Bahia, Brasil. Geocienses Rennes, França. Doctor of Philosophy Thesis, 193p.

Contribution IGC-097 Received March 1, 2000 Accepted for publication April 27, 2000 